Ann. Génét. Sél. anim., I980, 12 (2), I69-I80.

\title{
Blood groups and evolutionary relationships among domestic Sheep (Ovis aries), domestic Goat (Capra hircus), Aoudad (Ammotragus lervia) and european Mouflon (Ovis musimon)
}

\author{
T. C. NGUYEN and T. D. BUNCH (*)
}

Département de Génétique animale, Laboratoive de Génétique biochimique, Centre national de Recherches zootechniques, I.N.R.A., 78350 Jouy-en-Josas, France

$\left(^{*}\right)$ Department of Animal Dairy and Veterinary Sciences and International Sheep and Goat Institute Utah State University, Logan, Utah, U.S.A.

\section{Summary}

Data presented in this report are concerned with the results of blood typing of 7 aoudad (Ammotragus lervia), 20 european mouflons (Ovis musimon) and 260 domestic goats (Capra hircus). The blood samples were tested with 31 different sheep blood typing reagents to see if sheep-like blood-group antigens existed in the red cells of the three species. The polymorphism of serum transferrin and hemoglobin was analyzed by means of horizontal starch gel electrophoresis.

Evidence is presented for the existence in european mouflon of blood-group antigens similar to or identical with those recognized in the eight blood group systems of deomstic sheep (i.e., the sheep blood-group systems $A, B, C, D, M, R, F_{30}$ and $F 4 I$ ). The electrophoretic pattern of the mouflon transferrin is also identical with that of domestic sheep homozygous for the transferrin $D$ allele. Likewise, the two hemoglobin variants observed in mouflon are indistinguishable from the hemoglobins $A$ and $B$ of domestic sheep. On the basis of such extensive similarity in antigenic structures in the red cells and in the electrophoretic mobility of transferrins and hemoglobins, domestic sheep (Ovis aries) and european mouflon (Ovis musimon) may have close evolutionary affinity to each other.

The present data also indicate that both aoudad (Ammotragus levvia) and domestic goat (Cap Hircus) have blood-group antigens related to those of the $B, C, M, R$, and $F 30$ systems of sheep. With respect to serological reactions in the $M$ and $R$ systems, Ammotragus resembles Capra much more closely than Ovis. With respect to the $A$ system, however, Ammotragus appears to be more closely related to Ovis than to Capra; the latter, unlike Ammotragus, apparently does not have blood-group antigens related to those recognized in the $A$ system of sheep. On the other hand, the three genera seem to be quite distinct from each other on the basis of differences in the electrophoretic mobility of their major variants of transferrin and hemoglobin.

These observations, in conjunction with those reported earlier and mentioned in the introductory remarks of this report, suggest that Ammotragus is intermediate between Capra and Ovis. But, on the basis of the data presently available, it is not possible to establish more precisely the evolutionary relationships among the three genera. 


\section{Introduction}

The aoudad is a member of the tribe Caprini (family Bovidae) and shares affinities with both sheep (Ovis) and goats (Capra) (ELLLERMAN and MorrisonScotT, I95I; Thenius and HofFEr, I960; Geist, I97I). Ammotragus, together with the more primitive caprine, the Tahr (Hemitragus), also share behavioral and morphologial similarities with the goat antelopes (Rupicaprini), from which the caprines most likely evolved (TheniUs and HoFFER, I960; GEIST, I97I).

Anatomically, the aoudad most closely resembles goats (Table I). Although characteristically lacking the inguinal, preorbital and pedal glands that are common to Ovis, the aoudad is often referred to by its common name "Barbary Sheep ". The aoudad is unique among sheep and goats in having leggings or chaps of long hair that extend along the anterior surface of the forelegs. It also has a fringe of long hair which extends along the front of the neck to the brisket.

The aoudad is endemic to the mountainous regions of North Africa throughout the Sahara region " south to about $14^{\circ}$ near the Niger and through Tchad and Sudan to the Red Sea " (CORBETT, I978). Ammotragus literrally means " sand goat " in reference to its habitat and its color, which is a pale tawny brown or rufus grading to an off-white underside with dark brown areas about the head and forequarters (VALDEZ and BUNCH, I979). The aoudad is common in zoological parks throughout Europe, Asia and the United States and occurs as transplanted wild populations in California, New Mexico, and Texas.

Occasional hybridization between the aoudad and goat has produced offspring that expressed varying degrees of fertility. As a result, some taxonomists have reclassified the aoudad within the genus Capra (ANSELL, I97I; CORBETT, I978). There have been no reports of successfully crossing the aoudad with true sheep (Gray, I972). GeIST (I97I) has discounted the reclassification of Ammotragus because he believes that reproductive barriers arose between Ammotragus and Ovis due to their sympatric distribution in Notrh Africa during the Pleistocene, whereas wild Capra stock was never endemic to Africa.

Chromosome analyses of Ammotragus, Capra, and Ovis have demonstrated a common fundamental number of $58(\mathrm{FN}=$ total number of arms of autosomal chromosomes of the diploid set). All goats, both domestic (Capra hircus) and wild (C. hircus, $C$. ibex, and C. falconeri) have a $2 n$ of 60 and a FN of 58 (WURSTER and BenirschKe, I968: NAdLER and LAY, 1975). Ammotragus has a $2 n$ of 58 and a FN of 58 ( $\mathrm{HECK}$ et al., I968). Ovis has undergone a series of diploid chromosome reductions from 58 to 52 while maintaining a FN of 58 (SchMitT and UlBRICK, I968; WURSTER and BeNIRSCHKE, I968; NADLER, I97I; NADLER et al., I97I, I973a and $b$ and I974; NADLER and BUNCH, I978; BUNCH et al., I977; VALDEZ et al., I978). Giemsa-banding analyses of the $2 n=58$ karyotype of Ammotragus and Ovis have partially demonstrated longitudinal, structural homology with the goat karyotype (Evans et al., I973; NADLER et al., I974; BUNCH et al., I977; Bunch, I978). Acrocentrics I and 5 which have been maintained as single entities in the goat karyotype have been postulated as having given rise to the metacentric chromosomes of Ammotragus and the largest pair of metacentrics in Ovis (Bunch et al., I977; Bunch, 1978).

Cytogenetic, behavioral and, to some extent, morphological data have led some investigators to conclude that an Ammotragus-like form was directly ancestral 


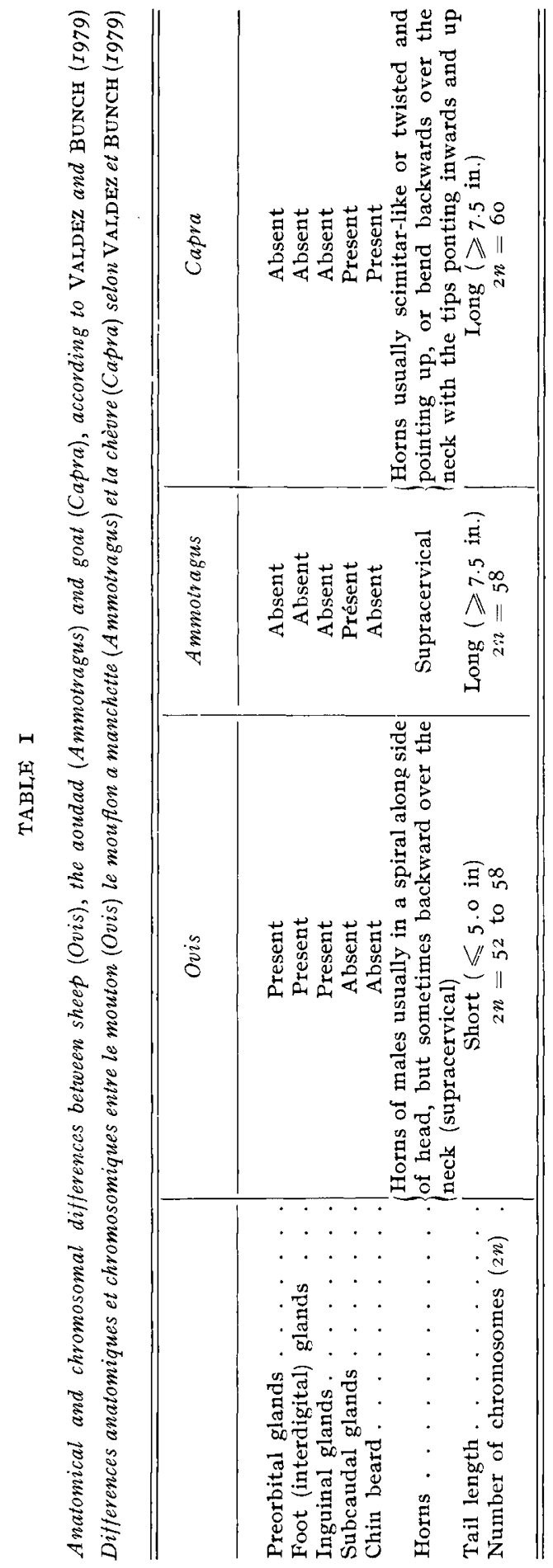


to Ovis (GEIST, I97I; NADLER et al., I974). However, amino-acid sequencing of homoglobin chains of all three species (MANWELL and BAKER, I975), as well as comparisons of their blood proteins by means of immunodiffusion (HIGHT and NADLER, I976) and electrophoric/techniques (MANWELI and BAkER, I977) have suggested that Ammotragus is no closer to Ovis than to Capra.

Since similarities and differences among blood-group antigens of cattle (Bos taurus), american bison, (Bison bison), domestic sheep (Ovis aries) and goat (Capra hircus), have been reported to reflect their taxonomic status (STORMon' et al., I96I; Stormont and Suzuki, I96r; NGUYen, I972 and r977), we used these antigenic structures of the red cells as an investigative tool in an attempt to assess the evolutionary relationships among Ammotragus, Ovis, and Capra.

Data presented in this report are concerned with the results of blood typing of 7 aoudads (A. lervia), 20 European mouflons (O. musimon) and 260 domestic goats $(C$. hircus), using $3 \mathrm{I}$ different sheep blood-group typing reagents. Bloodgroup antigens of the two wild species are then compared to each other and to those of domestic goats and sheep. In addition to the blood-group data, blood transferrins and hemoglobins of the four species are also compared, on the basis of their electrophoretic mobility in starch gel.

\section{Materials and methods}

\section{Blood Samples}

Blood samples were collected from I male and 6 female aoudads (Ammotragus lervia) maintained at Utah State University, Logan, Utah, U.S.A. Samples were heparinized to prevent clotting and air-freighted within 24 hours of collection to the Laboratoire de Génétique biochimique, C.N.R.Z., I.N.R.A., Jouy-en-Josas, France, for blood typing.

Among 20 european mouflons (Ovis musimon) examined (4 males and 16 females), four were sampled from the collection at the Ménagerie du Jardin des Plantes (a branch of the Museum National d'Histoire naturelle, Paris) and the remainder were from a collection at the Institut National de la Recherche Agronomique, Laboratoire des Pelages, Toisons et Fourrures, C.N.R.Z., Jouy-en-Josas, France. One of the four males examined had produced three offspring from two domestic ewes. The two ewes and these offspring were also blood-typed.

In recent years, we had typed 260 domestic goats (50 males and 2 Io females) representing three breeds kept in France (Alpine-Chamoisée, Poitevine, Saanen) and five breeds kept in Switzerland (Gemsfarbig, Saanen, Toggenburg, WalliserSchwarzhals, Verzasca-Nera (...) as well as 22I offspring from these goats.

\section{Blood Typing Reagents}

The reagents used in the present study had been developed at Jouy-enJosas, France, for the purpose of blood-group typing in domestic sheep. They have been used in testing more than 30 000 sheep during the past ten years. Most of these reagents are internationally classified reagents (e.g., $\mathrm{Aa}, \mathrm{Bb}, \mathrm{Ca}$ etc...); that is, they are specific for the well-known blood-group factors of domestic 
sheep (see NGyUEN, I973; Fesus, I977). All the reagents employed in the testing and listed below, had been proveci reactive in 8 genetic systems of blood-groups in sheep (NGUYen and RuFFet, I975; NGuYen, I978). They are: $A a, A b, F_{I} 6$, $F_{19}(A$ system); $B b, B c, B d, B e, B f, B g, B h, B i, F 4, F 8, F 26, F 35, F 38$ ( $B$ system); $C a, C b, F 5, F 6, F_{32}(C$ system); $D a(D$ system); $M a, M b, F 36$ ( $M$ system); $R, O,\left(R\right.$ system); $F_{30}$ and $F 4 I$ (2 new systems distinct from each other and from the well-known blood-group systems of sheep).

\section{Serologic and Electrophoretic Techniques}

Hemolytic and hemagglutination techniques, as described in previous reports (NGUYEN, I972; NGUYEN and RUFFET, I975), were used in the blood-group typing.

Transferrin and hemoglobin types were identified by horizontal starch gel electrophoresis (hydrolyzed starch from Connaught Laboratories, Toronto, Canada) according to the method described by SMiTHIEs (I955), using the discontinuous buffer system suggested by AshToN (1965) for the transferrins and that of GAHNE et al. (I960) for the hemoglobins.

\section{Results}

Reactions produced by $3 \mathrm{I}$ different sheep blood typing reagents with the red cells of 7 aoudads, 20 mouflons, and 260 goats are summarized in table 2 . In this table, the number of positive animals, with respect to each reagent, is given for each species, whereas a dash (-) indicates that no positive reaction has been observed in the sample. It must be noted that all the sheep reagents that crossreacted with the red cells of aoudads, mouflons, and goats, distinguished individual differences within each species. An exception, however, was observed with three reagents (namely $F_{35}, F 6$ and $F_{32}$ reagents) that cross-reacted with red cells of all the seven aoudads examined. By absorbing these three reagents with positive red cells taken from aoudad, mouflon, goat and sheep, it was shown that the reactions observed with the aoudad red cells could be attribued to the specific $F_{35}, F 6$, and $F_{32}$ antibodies in the corresponding reagents. The cross-reactions of these antibodies with all the seven aoudad were not unexpected since the number of aoudads tested was very small and the blood factors $F 6, F_{32}$, and $F_{35}$ occurred with relatively high frequency in both sheep and goats.

As indicated in table 2 , all four reagents reacting in the $A$ system of sheep did not cross-react with goat red cells. Three of them $\left(A \dot{a}, A b\right.$, and $\left.F_{I 9}\right)$, however, were reactive with the red cells of mouflons. The $A a$ and $A b$ reagents also crossreacted with aoudad red cells, but the $F_{I} 6$ and $F_{I 9}$ reagents did not. It should be mentioned that red cells of $A b$ positive sheep always reacted with one or both of the $F_{I} 6$ and $F_{I 9}$ reagents. This also applied to the mouflon red cells, since all the $A b$ positive mouflons were $F_{I 9}$ positive.

The $B$ system reagents of sheep cross-reacted extensively with red cells of all the three species studied. All the sheep blood factors identified in the $B$ system by our reagents have their counterparts in goats ('Table 2). Most but not all of them also have their homologues presently detectable in mouflons and aoudads. The very small number of aoudads and mouflons examined, however, 
TABLE 2

Sheep-like blood-group antigens detected in seven aoudads (Ammotragus levvia), 20 European mouflons (Ovis musimon) and 260 domestic Goats (Capra hircus) by 31 different sheep blood typing reagents.

$(A),(B)$ etc... indicate the sheep blood-group systems in which the reagents are reacting. For each species, the number of positive animals is given in regard to each reagent. A dash $(-)$ means that no positive reaction has been observed in the sample. An asterisk $\left(^{*}\right)$ indicates the presence of $O$ like blood-group substance in the serum but not on the red cells.

Antigènes de groupes sanguins du type mouton détectés chez 7 mouflons à manchette (Ammotragus levvia), 20 mouflons européens (Ovis musimon) et 260 chèvres domestiques (Capra hivcus) avec $3 I$ réactifs de groupes sanguins moutons.

$(A),(B)$, etc... correspondent aux systèmes de groupe sanguin mouton dans lesquels les réactifs réagissent. Pour chaque espèce, le nombre d'animaux positifs est donné en face de chaque réactif. Un tiré (-) signifie qu'aucune réaction positive n'a été observée dans l'échantillon. Une astérisque $\left(^{*}\right)$ indique la présence d'une substance antigénique semblable à $O$ dans le sérum pas mais dans les globules rouges.

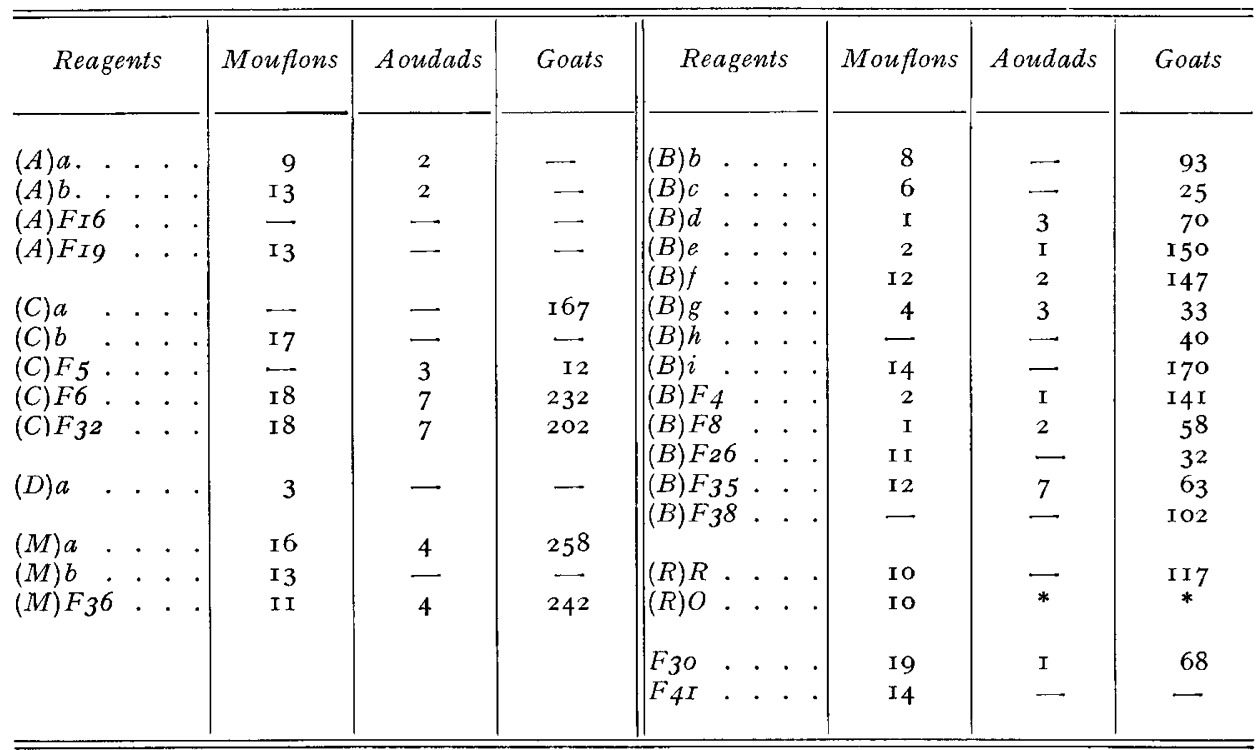

makes negative reactions with respect to any given reagent inconclusive relative to a lack of the corresponding blood group factor. Family data obtained in the present study confirmed our earlier observation (NGUYEN, I977) by showing that the blood factors detected in goats by the $B$ system reagents belong to a genetic system closely related to the $B$ system of sheep. Likewise, other limited family data also suggested that the mouflons possess a blood-group system that is fully equivalent to the $B$ system of sheep.

Among the five blood-group factors recognized in the $C$ system, only three are presently identified in aoudads (i.e., $F_{5}, F 6$, and $F_{32}$ ) and in mouflons (i.e., $C b, F 6$, and $F_{32}$ ), while four (i.e., $C a, F_{5}, F_{6}$, and $F_{32}$ ) have their equivalents in goats. In the latter species, family data confirmed the serological evidence for a blood-group system that is quite similar to the $C$ system of sheep.

As far as is known, the $D a$ reagent ( $D$ system of sheep) only cross reacted with the red cells of mouflons. The same was true for the $F 4 I$ reagent, which 
was recently obtained in our laboratory and defined as a new blood-group system in sheep.

The $M a$ an $M b$ reagents defined a closed blood-group system ( $M$ system) in sheep. That is, all Ma-negative sheep were always $M b$ positive and viceversa. The $F_{3} 6$ reagent was reactive with most but not all $M a$ - and $M a M b$ positive sheep and non-reactive with $M b$-positive sheep. As in sheep, the $F 36$ and $M a$ reagents distinguished individual differences in goats (Table 2). The red cells of all goats so far tested, including two $M a$-negative goats, were not reactive, however, with $M b$ reagents. The same pattern held true for the cross-reactions of these three $M$ system reagents with aoudad red cells. On the other hand, the reaction patterns exhibited by $M a, M b$, and $F 36$ reagents with the red cells of mouflons, duplicated those obtained in blood typing of sheep.

It has been well established that the $\mathrm{R}$ and $\mathrm{O}$ blood-group substances of sheep are serologically related, respectively, to the $J$ and $O g$ substances of goats, as well as to the $J$ and $O c$ substances of cattle. In all three species, these substances are primarily present in soluble form in blood plasma and other body fluids. The red cells of newborn animals do not have these substances, with $J$ or $R$ being acquired during the first three weeks after birth, hence becoming reactive with anti- $J$ (i.e., anti- $R$ of sheep). On the other hand, the $O$ substances can be readily detected in sheep red cells at about one month of age or older. In contrast, neither the $O c$ substance of cattle nor the $O g$ susbtance of goats can be demonstrated in the red cells of adult cattle and goats which do possess, however, the corresponding substance in their serum (see STORMoNT and SuzukI, I96I; SUzUkI and STORMONT, I96I and I962; RASMUSEN, I962). Therefore using anti- $J$ (i.e., anti- $R$ of sheep) and anti- $O$, sheep can be classified into three groups : $R, O$, and $i$, the latter designates sheep which do not have $R$ and $O$ substances in their serum or on their red cells. As the red cells of cattle and goats are nonreactive with anti- $O$, only two types of animals, (i.e., $J$-positive and $J$-negative), can be distinguished within each species. With respect to reactions to $J$ and $R$, goats appear to be more closely related to cattle than to sheep (STORMon'T and SUzUKI, I96I). Results presented in this report shown that, like goats all seven aoudads tested possess an $O$-like substance in their serum. But the aoudad red cells were nonreactive with both anti- $J$ (i.e., anti- $R$ of sheep) and anti- $O$. Among 20 mouflons tested, ten were $R$ (i.e., $J$ ) positive and possessed in their serum an $R$-like substance; the remainder were $O$ positive and possessed an $O$-like substance in their serum. The present data clearly indicate that sheep and mouflons are closely related with respect to the $R$ system, while the $J$ system of aoudads resembles the $J$ system of goats much more closely than it does the $R$ system of sheep and mouflons.

Our $F_{30}$ reagent, apparently non-reactive with cattle red cells, identified, in sheep another blood-group system that has its counterpart in goats (NGUYEN, I977). The $F_{30}$ reagent also distinguished individual differences in aoudads and in mouflons.

In domestic sheep, serum transferrins display a high degree of polymorphism, which is under the genetic control of a series of codominant alleles. On the basis of differences in electrophoretic mobility in starch gel, at least 20 different variants of sheep transferrin have been reported in the literature. Some of these were only detected in a few samples without evidence for their genetic control. Other variants occurred only in certain breeds or flocks with low frequency, except for the transferrin variants $A, B, C, D$, and $E$, which have been recognized in various breeds by several investigators (see STRATIL, I973; RASMUSEN and TUCKER, 
I973). Results obtained in this study clearly showed that the two variants of goat transferrin differed in mobility from the well-known sheep transferrins $I$, $A, G, B, C, M, D, E$, and $P$ (in descending order of mobility rate). No polymorphism was observed however, in the transferrin system of aoudads or mouflons tested in our laboratory. Under the electrophoretic conditions used, the aoudad transferrin migrated between the sheep transferrins $C$ and $M$, its position was somewhat more cathodal than that of the fast moving variant of goat transferrins. The slow moving variant of goat transferrins migrated between the $D$ and $E$ variants of sheep. On the other hand, the mouflon transferrin could not be distinguished from sheep transferrin $D$ on the basis of electrophoretic mobility. Moreover, among three animals born from matings between a male mouflon and two domestic ewes, one received the maternal transferrin $D$ and had an electrophoretic pattern of transferrin identical with that of sheep homozygous for the transferrin $D$ allele. The electrophoretic patterns of the other two were identical with those of sheep with $B D$ and $D E$ types, respectively.

In domestic sheep, two hemoglobin variants $A$ and $B(A$ being more anodal than $B$ ) were recognized by horizontal electrophoretic technique in normal adult animals. Also, two normal, adult hemoglobin variants could be identified in each of the three species examined in this study. The two variants observed in mouflons were quite similar in electrophoretic mobility, to sheep $A$ and $B$ variants, respectively. In goats, the fast moving and common hemoglobin variant appeared to be somewhat similar in mobility to the slow moving $B$ variant of sheep. The aoudad fast moving hemoglobin variant migrated more slowly than the sheep variant $A$, but more quickly than the $B$ variant of sheep and the fast moving variant of goats. The mobilities of the latter two variants did, however, exceed that of the aoudad slow hemoglobin variant which, in turn, was faster than the slow variant of goats.

On the basis of differences in electrophoretic migration velocities of transferrins and hemoglobins, sheep, and mouflons were quite similar to each other, while the aoudads and goats could be easily distinguished from each other and from sheep and mouflons.

\section{Discussion}

I)ata presented in this report provide serological evidence for the existence, in european mouflons (Ovis musimon) and aoudads (Ammotragus lervia), of several blood-group antigens similar to or identical with those recognized in domestic sheep (Ovis aries).

The existence, in both aoudads and European mouflons, of blood-group antigens related to those of the $B, C, M$, and $R$ systems of sheep is not unexpected, since information from previous studies (STORMONT and SUzUKI, I96I; NGUYEN, I972 and I977; NGUYEN et al., I975) showed that these four blood-group systems of sheep have their counterparts in goats (Capra hircus) and cattle (Bos taurus) and appear to be conservative in the evolution of these gene loci.

The present data also show that, like goats, european mouflons and aoudads possess another blood-group antigen that is related to the antigen of the $F_{3} O$ system of sheep.

With respect to reactions in the $M$ and $R$ systems, sheep and european mouflons (Ovis) exibit close relationships to each other, while the aoudads ( $\mathrm{Ammo-}$ 
tragus) appear to be more closely related to goats (Capra) than to Ovis. On the other hand, both aoudads (Ammotragus) and European mouflons (Ovis) but apparently not goats ( $\mathrm{Capra}$ ), possess blood-group antigens related to those recognized in the A system of domestic sheep (Ovis aries).

In regard to the $D$ and $F 4 I$ blood-group systems, all we can say at present is that sheep and european mouflons (Ovis) have in common the antigens $D a$ and $F 4 I$, but there is no indication of these antigens in goats (Capra) and aoudads (Ammotragus). Further studies are needed to define more precisely the distribution of these antigens among related species.

It must be noted that the present study, as accomplished solely with sheep reagents, does not of course exclude the existence in goats, aoudads, and European mouflons of blood-group antigens not found in sheep. Obviously, such antigens exist in goats and have been already observed (EHRLICH and MORGENROTH, I9Oo; unpublished data obtained in our laboratory). There is, however, no evidence for such antigens in aoudads and european mouflons. But they might be expected to exist, at least in the aoudads (Ammotragus), which differ from Ovis in certain blood protein antigenic characters (HIGHT and NADLER, I976).

In this connection, Ammotragus, Capra, and Ovis can be distinguished from each other on the basis of differences in electrophoretic mobility of certain blood proteins (MANWELI, and BAKER, I977). Results of transferrin and hemoglobin comparisons presented in this report, like the blood-group data, provide evidence for a close evolutionary relationship between the two species of the genus Ovis examined. In contrast to earlier observations (NADLER et al., I97I; SPILLETT et al., I975), no polymorphism has been observed in the transferrin system of the european mouflons (Ovis musimon) examined in this study. On the other hand, the present data are in accordance with those (MANWELI and BAKER, I977; VALDEZ and BUNCH, I979) showing that two normal adult hemoglobin variants can be distinguished in aoudads (Ammotragus), whereas no polymorphism has been observed in the transferrin system. Under the electrophoretic conditions used in this study, it also appears that aoudads (Ammotragus) and goats (Capra) are distinct from each other and from $O$ vis with respect to differences in electrophoretic mobility of their major variants of transferrin and hemoglobin.

In conclusion, the overall results presented in this report clearly indicate close evolutionary affinity of the European mouflon (Ovis musimon) to domestic sheep (Ovis aries). Indeed, the relationship is close enough to justify the opinion stated by BuNCH et al. (I976 and 1978) that, in view of the close similarity suggested by chromosome and hemoglobin comparison, the european mouflon or, very likely, its original parent stock should be considered ancestral to modern breeds of domestic sheep. According to the present data and to those reported earlier (Hight and Nadler, I976; MANwell and BAKER, 1977), Ammotragus appears to be intermediary between Ovis and Capra; but, as already mentioned in previous reports, it is not possible to establish more precisely their evolutionary relationships. Since the process of animal evolution is not simple and does not always conform to the model of independant evolution without hybridization, it is not surprising that the evolutionary history of the three genera is difficult to reconstruct. Further investigations could undoubtedly provide additional information, but in this study it was not possible to determine if Ammotragus is, in fact, a "Sand Goat " or a "Barbary Sheep". 


\section{Résumé}

\section{Groupes sanguins et relations évolutives entre le mouton (Ovis Aries), la chèvre (Capra Hircus), le mouflon à manchettes (Ammotragus Lervia) et le moutlon d'Europe (Ovis Musimon)}

Les antigènes érythrocytaires de 7 mouflons à manchettes (Ammotragus levvia), de 20 mouflons d'Europe (Ovis musimon) et de 260 chèvres (Capra hircus) ont été examinés à l'aiđe de $3 \mathrm{I}$ réactifs préparés pour la détermination des groupes sanguins đu mouton (Ovis aries). Le polymorphisme de la transferrine sérique et de l'hémoglobine de ces différentes espèces a été analysé par la technique d'électrophorèse en gel d'amidon.

Les résultats de ces examens sérologiques ont montré que le mouflon d'Europe possède des antigènes de groupes sanguins similaires ou identiques à ceux qui font partie đe 8 systèmes de groupes sanguins définis chez le mouton (systèmes $A, B, C, D, M, R, F_{30}$ et $F_{4 I}$. Ces 2 espèces du genre Ovis ne peuvent, d'ailleurs, être distinguées 1'une à l'autre, sur la base de la mobilité électrophorétique de leur transferrine et de leur hémoglobine. Cette très grande ressemblance, tout au moins en ce qui concerne les caractères sanguins considérés, indique clairement que le mouflon d'Europe (Ovis musimon) et le mouton (Ovis aries) sont très proches l'un de l'autre sur 1'échelle zoologique des espèces et que leur séparation doit donc être récente.

Les résultats de cette comparaison ont révélé, en outre, que le mouflon à manchettes ( $A m m o$ tragus) et la chèvre (Capra) possèdent également des antigènes de groupes sanguins similaires à ceux qui sont reconnus dans les systèmes $B, C, M, R$ et $F 30$ du mouton. Cependant, si les réactions sérologiques observées dans les systèmes $M$ et $R$ suggèrent que 1'Ammotragus se rapproche plus du genre Capra que du genre Ovis, les données concernant le système $A$ indiquent que l' $A m$ motragus paraît être plus proche du genre Ovis que du genre Capra. D'autre part, ces 3 genres semblent se différencier nettement entre eux, sur la base de la mobilité électrophorétique de leur transferrine et de leur hémoglobine.

Ces observations, ainsi que celles rapportées dans la littérature et mentionnées dans ce rapport, permettent de penser que, sur l'échelle évolutive des espèces, l'Ammotragus occupe une position intermédiaire entre les genres Capra et Ovis. Dans l'état actuel des connaissances, iln'est pas possible d'établir, avec plus de précision, les relations évolutives entre les 3 genres Capra, Ovis et Ammotragus.

\section{References}

ANselL W. F. H., I97I. Order Artiodactyla. Pp. I-84 in J. Meester and H. W. Setser (eds.). The Mammals of Africa, An identification Manual. Smithsonian Institution Press, Washington. AshTon G. C., r965. Serum Transferrin D alleles in Australian Cattle. Austr. J. Biol. Sci., 18, $665-670$.

Bunch T. D., I978. Fundamental karyotype in domestic and wild species of sheep. J. Hered., 69, $77-8$ o.

Bunch T. D., Foote W. C., SPILLETT J. J., I976. Translocations of acrocentric chromosomes and their implications in the evolution of sheep (Ovis). Cytogenet. Cell Genet., 17, I22-136.

Bunch T. D., Nguven T. C., Lauvergne J. J., I978. Hemoglobins of the Corsico-Sardinian Mouflon (Ovis musimon) and their implications for the origin of $\mathrm{HbA}$ in domestic sheep (Ovis aries). Ann. Génét. Sél. Anim., 10, 503-506.

BUNCH T. D., ROGERS A., FOOTE W. C., 1977. G-band and transferrin analysis of aoudad-goat hybrids. J. Heved., 68, 210-2 I 2 .

Corbett G. B., I978. The Mammals of the Palearactic Region: A Taxonomic Review. Cornell University Press, Ithaca.

EHrlich P., MorgenRoth J., igoo. Ueber Haemolysine. Berlin Klin. Wochensch, 37, 453-458.

EILERMAN J. R., MOORISON-SCOTT T. C. S., I95I. Checklist of Palearctic and Indian Mammals, I 758-I946. British Museum (Nat. Hist.) London.

Evans H. J., Buckiand R. A., Summer A. T., 1973. Chromosome homology and heterchromatin in goat, sheep and ox studied by banding techniques. Chromosoma, 42, 383-402. 
FÉsus L., 1977. Report on the Third International Comparison Test for Sheep Blood typing reagents and for red cells and serum protein and enzyme polymorphisms. Anim. Blood Grps. Biochem. Genet., 8, 45-46.

GAHNE B., RENDEL J., VENGE O., I960. Inheritance of $\beta$ globulins in serum and milk of cattle. Nature London, 186, 907-908.

GEIST V., I97I. Moutain Sheep. A study in Behavior and Evolution. Univ. of Chicago Press, Chicago.

GRAY A. P., 1972. Mammalian Hybrids. Commonwealth Agricultural Bureaux Farnham Royal, England.

HECK H., WURSTER D., BENIRSchke K., 1968. Chromosome study of members of the subfamilies Caprinae, Bovinae, family Bovidae; the musk ox, ibex, aoudad, Congo buffalo and gaur. Z. Saügetierk, 33, I 72-I79.

Hight M. E., NADLER C. F., I976. Relationships between sheep and goats and the aoudad (Caprini) studied by immunodiffusion. Comp. Biochem. Physiol., 54 (2B), 265-269.

MANWELL C., BAKer C. M. A., I975. Ammotragus lervia : Progenitor of the domesticated sheep or specialized offshoot of Caprine evolution? Experientia, 31, I370-1 371 .

MANWELL C., BAKER C. M. A., I977. Ammotragus lervia : Barbary sheep or Barbary goat? Comp. Biochem. Physiol., 58 B, 267-27I.

NADLER C. F., I97I. Chromosomes of the dall sheep, (Ovis dalli dalli) Nelson. J. Mammal., $51,46 \mathrm{I}-463$.

NADLER C. F., Bunch T. D., I 978 . G-band patterns of the Siberian snow sheep (Ovis nivicola) and their relationship to chromosomal evolution in sheep. Cytogenet. Cell Genet., 19, ro8-I I7.

NADLER C. F., HOFFMANN F. S., WOOLF A., I973a. G-band patterns as chromosomal markers and the interpretation of chromosomal evolution in wild sheep (Ovis). Experientia, 29 II 7-II9.

NadleR C. F., Korobitsyna K. V., Hoffmann F. S., Vorontsov N. N., r973b. Cytogenetic differentiation, geographic distribution, and domestication in Paleartic sieep (Ovis). $Z$. Saügetierkunde, 38, ro9-I25.

NADLER C. F., HOFFMANN F. S., WOOLF A., I974. G-band patterns, chromosomal homologies, and evolutionary relationships among wild sheep, goats and aoudads (Mammalia, Artiodactyla). Experientia, 30, 744-746.

NADLER C. F., LAY D. M., 1975. Chromosomes of some Asian wild sheep (Ovis) and goats (Capra). Chrom. Inform. Ser., 18, 28-3I.

NADler C. F., LAy D. M., HAssinger J. D., I97I. Cytogenetic analysis of wild sheep populations in northern Irati. Cytogenetics, 10, I $37-\mathrm{r} 52$.

NADLER C. F., WOOLF A., HARRIS K. F., I97I. The transferrins and hemoglobins of bighorn sheep (Ovis canadensis), dall sheep (Ovis dalli) and mouflon (Ovis musimon). Comp. Biochem. Physiol. 40B, 567-570.

NGUYEN T. C., I972. Les groupes sanguins des ovins. I. Relations entre les groupes sanguins des ovins et des bovins. Ann. Génét. Sél. Anim., 4, 363-374.

NGUYen T. C., r973. Report on the sheep blood group workshop. Anim. Blood Grps. Biochem. Genet., 4, 24I-243.

NGUYEN T. C., I977. Further investigations on the relationships between blood groups of sheep and goats. Anim. Blood Grps. Biochem. Genet., 8, (Supplement I) I I - 2.

NGUYEN T. C., 1978. Additional blood group systems in sheep. Abstracts of papers read at the XVIth Intern. Conf. Anim. Blood Grps. and Biochem. Polymorhism (Leningrad, I978) II2.

NGUYEN T. C., RUFFET G., r975. Les groupes sanguins des ovins. II. Facteurs antigéniques supplémentaires dans les systèmes $A, B, C$, et $M$. Ann. Génét. Sél. Anim., 7, I45-157.

NGUyen T. C., Boulanger A., RAynaud C., I975. Les groupes sanguins et le polymorphisme des protéines du sang en espèce caprine. Journées de la recherche ovine et caprine. SPE,OC, Paris, Tome I, I09-I I8.

RASMUSEN B. A., 1962. Blood groups in sheep. Ann. N. Y. Acad. Sci., 97, 306-319.

RASMUSEN B. A., TUCkeR E. M., I973. Transferrin types and reproduction in sheep. Anim. Blood Grps. Biochem. Genet., 4, 207-220.

SchmitT J., UlbRich F., I968. Die chromosomen verschiedener Caprini, Simpson, I945. Z. getierk, 33, I80-186.

SmithiEs O., I955. Zone electrophoresis in starch gels. Group variations in the serum proteins of normal human adults. Biochem. J., 61, 629-64 I.

SPILLETT J. J., FOOTE W. C., BUNCH T. D., I975. Chromosomes and blood analysis of wild and domestic sheep. Desert Bighorn Council Transactions, 46-50. 
STORMONT C., SUzUKI Y., I96r. Blood group comparisons of cattle, sheep, and goats. ImmunoSaügenetics Letter (2) 48-49.

StormonT C., MILLER W. J., SUzUki Y., I96I. Blood groups and the taxonomic status of American Buffalo and domestic cattle. Evolution, 15, 196-208.

Stratil A., 1973. Two new sheep transferrin variants and the effect of neuraminidase. Anim. Blood Grps. Biochem. Genet., 4, I53-159.

SUzUki Y., Sorrmont C., I961. The $J$ system of goats. Immunogenetics Letter, (2) 67-68.

SUzUkI Y., STomont C., 1962. Additional notes on the $J$ system of goats Immunogenetics Letter, (2) $139-140$.

ThENIUS E., HOFER H., I960. Stammesgesichte dev Saügetieve. Springer Verlag, Berlin/Heidelberg/New York.

VALDEZ R., Bunch T. D., I979. Systematics of the aoudad (In Press).

VALDEZ R., NADleR C. F., Bunch T. D., 1978. Evolution of wild sheep in Iran. Evolution, 32, 56-72.

WURSTER D. H., BENIRSCHKE K., I968. Chromosome studies in the superfamily Bovidae. Chromosoma, 25, I 52-I 7I. 